\title{
The Adjudication of Marriage Disputes through Mediation at the Manado Religious Court
}

\author{
Faradila Hasan \\ Institut Agama Islam Negeri Manado \\ E-mail: faradila.hasan@iain-manado.ac.id \\ Nasruddin Yusuf \\ Institut Agama Islam Negeri Manado \\ E-mail: nasruddin.yusuf@iain-manado.ac.id \\ Moh. Muzwir R. Luntajo \\ Institut Agama Islam Negeri Manado \\ E-mail: muzwir.luntajo@gmail.com
}

\begin{abstract}
The phenomenon of marital disputes that often end in divorce has been a serious concern of the government, resulting in a regulation on mediation, namely the Regulation of the Supreme Court of Republic of Indonesia (PERMA) Number 1 of 2016. This regulation was made with the hope of reducing the divorce rate caused by marriage disputes. This article discusses the form of marriage dispute resolution at Manado Religious Court with a focus on one type of dispute resolution, namely mediation. This study uses an empirical juridical approach. The research was conducted at the Manado City Religious Court in 2017 and 2020. The result is that the mediation process has been carried out in accordance with the provisions of PERMA No.1 of 2016. However, there have been many obstacles. Thus, the efforts to reduce the divorce rate due to marriage disputes have not undergone significant changes.
\end{abstract}

Keywords: mediation; marriage dispute; Manado religious court.

\begin{abstract}
Abstrak: Fenomena sengketa perkawinan yang sering berakhir pada perceraian menjadi perhatian serius dari pemerintah sehingga melahirkan aturan tentang mediasi yaitu Peraturan Mahkamah Agung RI (PERMA) No. 1 Tahun 2016. Aturan ini dibuat dengan harapan menekan angka perceraian yang diakibatkan oleh sengketa perkawinan. Artikel ini membahas mengenai bentuk penyelesaian sengketa perkawinan di Pengadilan Agama Manado dengan fokus pada salah satu jenis penyelesaian sengketa yaitu mediasi. Penelitian ini menggunakan pendekatan yuridis empiris. Penelitian ini dilakukan di Pengadilan Agama Kota Manado pada tahun 2017 dan tahun 2020. Hasilnya adalah proses mediasi sudah dilakukan sesuai dengan ketentuan PERMA No.1 Tahun 2016. Namun mengalami benyak kendala sehingga upaya untuk menekan angka perceraian akibat sengketa perkawinan belum mengalami perubahan yang signifikan.

Kata-kata kunci: mediasi; sengketa perkawinan; pengadilan agama Manado.
\end{abstract}




\section{Introduction}

The noble ideal of marriage is to establish a relationship between husband and wife, so it is important to set a commitment to stay together. The commitment setted must be maintained and communicated as good as possible so that there is not any conflict between husband and wife which can lead to disputes in the marriage. The disputes do not only occur in marriage life but also occurs in society.

In carrying out life activities, contacts between humans and legal entities, whether in the form of interpersonal relationships or business transactions, can cause reactions. Such contacts can lead to positive business reactions. The reactions which do not harm any party, cause a dispute ${ }^{1}$. The completion of disputes through mediation can be equated with the dispute resolution through "hakam" and its operational form is "tahkim" which is stated in the Qur'an. Conflicts that continue to become disputes in the court often occur in Republic of Indonesia, both criminal and civil in nature. ${ }^{2}$

It can be seen from the subject that the conflict which is individual or group matter, can also be family matter in nature. Conflicts that occur in society continue to become cases if a person feels that his/her rights are disturbed then he/she submits a lawsuit to the court and after being officially registered, it then becomes a case. In this regard, case handling in Indonesia has now created serious problems for the accumulation of cases at the first, appeal, and cassation level.

The philosophical foundation of conflict resolution through mediation was carried out by Muhammad Rasulullah SAW, both before becoming an apostle and after becoming an apostle. The process of conflict resolution (dispute) can be found in the re-laying of the "Hajar Aswad (black stone on the side of the Ka'bah) and the Hudaibiyah agreement. These two events are well-known by Muslims around the world, and thus it is generally accepted. The Hudaibiyah agreement has values and conflict resolution strategies (disputes), especially mediation and negotiation, so that these two events have the same perspective, namely realizing peace. ${ }^{3}$

The take and give compromise attitude was shown by the Prophet Muhammad in the Hudaibiyah agreement. The mediator or parties must understand that dispute resolution through mediation is impossible to fulfill all of their demands, and then try to understand each other and reject the attraction of both parties. In this case, there is an element of giving and there is an element of receiving from both parties, so that no one feels disadvantaged by one another. In connection to these problems, ideas and

\footnotetext{
1 Jimmy Joses Sembiring, Cara Menyelesaikan Sengketa di Luar Pengadilan: Negosiasi, Mediasi, Konsiliasi \& Arbitrase, 1st ed. Jakarta: Visimedia, 2011, p. 1

2 Wirhanuddin, Deskripsi Tentang Mediasi di Pengadilan Tinggi Agama Makassar: Perspektif Hukum Islam, Al-Fikr, Vol. 20, No. 2. 2016, p. 279-303

3 Syahrisal Abbas, Mediasi dalam Hukum Syariah, Hukum Adat. \& Hukum Nasional Jakarta: Kencana, 2011, p.166
} 
efforts emerged to resolve disputes outside the litigation system (outside the court), looking for ways that were more efficient and effective, simple, fast and low cost and satisfying the disputing parties ${ }^{4}$, one of the ways that taken is mediation. In theory, mediation is an alternative to dispute resolution outside the judiciary, but it used to become an alternative for dispute resolution in court, especially in religious courts for matters related to marriage.

In the past, divorce occurred mostly because of the husband's will. This is because of the husband's position in the family was much stronger than the wife. The wife was more dependent on her husband materially and psychologically. If a divorce happened, the wife and children would feel the negative impact more ${ }^{5}$. However, from the data, this is different in Manado Religious Court that handle more cases for legal divorce, meaning that more wives pursue the divorce than the husbands at the Religious Courts.

The most cases that cause disputes in marriage occur because of divorce, both suicidal and divorce. The phenomenon of divorce in religious courts from 2 January 2015 to 20 November 2020 was recorded 2,481 cases handled by the Manado Religious Court. ${ }^{6}$ Meanwhile, the data from 2015 to 2017 were mediated marital disputes; 292 cases, 278 failed cases in mediation and 15 cases were successful. The high number of cases that failed to be mediated is certainly a big task for the mediators to carry out a deeper study of the effective mediation process so that it can reduce the number of failed mediation cases which simultaneously reduce the divorce rate in Manado City.

So far, research and studies on mediated marital disputes have been carried out by previous researchers, but those that specifically discuss marriage disputes are still limited in number, including research written by Erik Sabti Rahmawati ${ }^{7}$, Adiyono ${ }^{8}$ and Dodo Mustakid ${ }^{9}$ where mediation is carried out at the Religious Court. Malang and Bangkalan Districts as well as the mediation process in general in the religious courts have been carried out in accordance to the mechanisms stipulated in the Regulation of the Supreme Court of the Republic of Indonesia (PERMA) No. 1 of 2016 although in some cases it has not run according to the stipulated provisions. These three

4 Wirhanuddin, Deskripsi Tentang Mediasi di Pengadilan Tinggi Agama Makassar: Perspektif Hukum Islam. AL-FIKR, Vol 20, No. 2. 2016, p. 279-303.

5 Edi Gunawan and Faradila Hasan, Divorce Lawsuit Due to Polygamy in the Manado Religious Court, Al-Mizan, Vol. 13, no. 2, December 1, 2017, hlm. 272-293, http://journal.iaingorontalo.ac.id/index.php/am/article/view/914.

6 Pengadilan Agama Manado, Sistem Informasi Penelusuran Perkara, Pengadilan Agama Manado, accessed November 22, 2020, http://sipp.pa-manado.go.id/list_perkara.

7 Erik Sabti Rahmawati, Implikasi Mediasi Bagi Para Pihak yang Berperkara Di Pengadilan Agama Malang, De Jure: Jurnal Hukum dan Syar'iah, Vol. 8, No. 1 2016, p. 1-14.

${ }^{8}$ Dodo Mustakid, Proses Mediasi Perkara Perceraian di Peradilan Agama, Jurnal Edu Law: Jurnal Of Islamic Law and Yurisprudance Proses, Vol.1, No. 1,2020, p. 21-30.

${ }_{9}^{9}$ Adiyono, Mediasi Sebagai Upaya Hakim Menekan Perceraian di Pengadilan Agama, Al- Ihkam, Vol. 8, No. 1, 2013 p. 126-140. 
studies only examine the implementation of mediation whether or not it is in accordance with PERMA No. 1 of 2016.

Another research related to mediation was written by Ridwan Jamal with the title Resolution of Marriage Conflict through Mediation in Divorce Cases at Manado Religious Court. This article discusses conflict resolution in divorce cases at the Manado Religious Court. According to Jamal, the model of marital conflict resolution through mediation in divorce cases at Manado Religious Court is based on consensus by the parties mediated by a judge mediator, while non-judge mediator has not been practiced. However, there are factors that constrain the failure of marital conflict resolution through mediation in divorce cases at Manado Religious Court, namely the limited number of mediating judges as well as the facilities and infrastructure at Manado Religious Court which hinders the mediation process in marital disputes. The main obstacle experienced was that the plaintiff and defendant did not accept mediation ${ }^{10}$.

The role of the judge as a mediator is certainly very influential in terms of resolving marital disputes. In line with the role of the judge as a mediator Febry Andika Putri, Indra Perdan and Emiel Salim Siregar wrote that the factors that influence the success or failure of mediation in a divorce case are that both parties do not want to be together anymore or both parties do not attend the trial schedule / agenda that has been determined by Kisaran Religious Court. ${ }^{11}$

In terms of the effectiveness of mediation at the religious court, Mochamad Samsukadi and Ahmad Abdu wrote an article examining the effectiveness of mediation at the Jombang Religious Court during 2013-2014. The results show that the effectiveness of mediation can be seen from two aspects; in terms of function and results. In terms of function, mediation at Jombang Religious Court in 2013-2014 has been effective, but in terms of results there are still very few mediated cases that have ended and no divorce occurs ${ }^{12}$.

Furthermore, related to coaching, Noval Besse wrote about the practice of mediation at the Marriage Advisory and Preservation Agency (BP4). Noval Besse found BP4 in North Minhasa District used several applied methods, namely; informative methods--which have the character of providing information; suggestion and persuasive methods--ways to influence clients to be willing to follow the advice given; educational methods-the ways of giving educational advice; discussion method--which leads to problem solving by explaining the problems faced by clients; and a preaching method

10 Ridwan Jamal, Resolusi Konflik Perkawinan Melalui Mediasi dalam Perkara Perceraian di Pengadilan Agama Manado, Jurnal Ilmiah Al-Syir'ah, Vol. 15, No. 2, 2017.

${ }^{11}$ Febry Andika Putri, Indra Perdana, and Emiel Salim Siregar, Peranan Hakim Sebagai Mediator dalam Proses Mediasi untuk Menangani Perkara Perceraian Studi di Pengadilan Agama Kisaran Nomor: 1414/Pdt.G/2019/PA.Kis. Vol.1, No. 2, 2020, p. 268-273.

12 Mochamad Samsukadi and Ahmad Abdu, Efektifitas Mediasi dalam Menyelasaikan Konflik Pernikahan di Pengadilan Agama Jombang Tahun 2013-2014, Jurnal Hukum Keluarga Islam, Vol. 1, No. 1. 2016, p. 1-15. 
to calm their hearts. As a result, by applying these methods, all mediations can run effectively and successfully ${ }^{13}$. However, Zahrotul Hamidah who carried out research in Malang City found several obstacles experienced by BP4, including: 1) the client was introvert. 2) One of the client's was not willing to be contacted and asked for information 3) There are changes in government regulations. 4) The attitude of the client who insists on divorce. 5) Lack of socialization to the public regarding the existence of BP4. Due to various obstacles, the prevention of divorce in the Klojen District, Malang City is still unsuccessful and the divorce rate continues to increase. ${ }^{14}$

Based on the phenomenon and previous studies, the focus of this article is on mediation procedures in terms of dispute resolution at Manado Religious Court. This research examines the mediation procedure at the Manado Religious Court with indicators of whether or not the evaluation is based on the results of a questionnaire which contains 20 questions to 10 informants including judges, clerks, clerks of seizures, administrative staff and litigants at the Manado Religious Court.

This research uses an empirical juridical approach. This research was conducted at Manado City Religious Court in 2017 and 2020. The data was obtained from the results of filling out a questionnaire with 20 questions to 10 respondents who worked at Manado Religious Court, including judges, clerks, clerks, administrative staff and other parties litigated at Manado Religious Court from 2015 to 2017. Other data was also obtained from the Manado Religious Court Case Tracking Information System Website, namely the number of divorce cases, either divorced or sued from 2018 to 2020.

\section{Marriage and Peace Disputes}

Basically, no one wants a dispute with another person. But in a business or an agreement, each party must anticipate the possibility of a dispute that can occur at any time in the future. Disputes that need to be anticipated can arise because of differences in the interpretation, both regarding how to implement the agreement clauses and about the contents of the provisions in the agreement, or for other reasons. ${ }^{15}$

The disputes can be caused by several factors, including differences in interests or disputes between one party and another. It can also be caused by the existence of rigid rules that are considered as obstacles and the obstacles

13 Noval Besse, Praktik Mediasi Pada Badan Penasehatan Pembinaan dan Pelestarian Perkawinan di Kabupaten Minahasa Utara, Aqlam: Journal of Islam and Plurality Vol. 3, No. 2 2018.

14 Zahrotul Hamidah, Peran Badan Penasihat, Pembinaan dan Pelestarian Perkawinan (BP4) dalam Mencegah Perceraian (Studi Kasus di KUA Kecamatan Klojen Kota Malang), HIKMATINA: Jurnal Ilmiah Hukum, Vol.1. 2019, p. 12-23.

15 Gatot P. Soemartono, Arbitrasedan Mediasi di Indonesia, Jakarta: PT. Gramedia Pustaka Utama, 2006, p.1. 
to achieve the goals of each party. Because each party will make every effort to achieve its goals, so the potential for disputes is even greater. ${ }^{16}$

The dispute occurred must be resolved by the parties. The resolution of these disputes can be done through the court or outside the court. The settlement of disputes through courts is guided by the Procedural Law which regulates the requirements that must be met, so that a dispute can be submitted and the measures can be taken. Meanwhile, out of court dispute settlement is the dispute settlement based on the agreement of the parties and the settlement procedure for a dispute is fully distributed to the disputing parties. Out of court dispute resolution can be carried out in various ways including negotiation, mediation, conciliation and arbitration. ${ }^{17}$ The dispute settlement has its own advantages and disadvantages that can be taken into consideration by the parties in choosing a dispute resolution program. ${ }^{18}$

Mediation comes from the English which means dispute resolution involving a third party as an intermediary or mediating dispute resolution, the mediator is the person who mediates ${ }^{19}$. Mediation is also known as dading, which is a written agreement amicably to settle or to stop a case from continuing in ${ }^{20}$. In Law Number 30 of 1999 concerning Arbitration and Alternative Dispute Resolution in article 6 paragraph 3 there is no definition of mediation, but only provides information that if the dispute does not reach an agreement, the dispute can be resolved through an expert advisor or a mediator ${ }^{21}$.

Meanwhile in PERMA No. 1 of 2016 on the Mediation Procedure in Court in article 1 paragraph 1 defines mediation as a way of resolving disputes through the negotiation process to obtain an agreement between the Parties with the assistance of a Mediator. ${ }^{22}$

Some important elements in mediation include the following: (1) Mediation is the process of dispute resolution based on negotiation; (2) The mediator is involved and accepted by the disputing parties in the

16 Sembiring, Cara Menyelesaikan Sengketa di Luar Pengadilan Negosiasi, Mediasi, Konsiliasi \& Arbitrase, p. 1-2.

17 Sembiring, Cara Menyelesaikan Sengketa di Luar Pengadilan Negosiasi, Mediasi, Konsiliasi \& Arbitrase; Aprilda, Pengaruh Kompetensi Terhadap Prestasi Kerja Pegawai (Studi Pada Bagian Pengelolaan Keuangan Balai Pengembangan Pendidikan Nonformal dan Informal Regional I Medan) Pemerintah Provinsi Sumatera Utara Pengetahuan, Keahlian dan Sikap Prilaku Tugasnya, Jurnal Administrasi Publik, No. 2, 2012, hlm. 181-206; Nurnaningsih Amriani, Mediasi Alternatif Penyelesaian Sengketa Perdata di Pengadilan, Jakarta: Rajawali Press, 2012.

18 Sembiring, Cara Menyelesaikan Sengketa di Luar Pengadilan Negosiasi, Mediasi, Konsiliasi \& Arbitrase, p. 2.

19 Abdul Manan, Penerapan Hukum Acara Perdata di Lingkungan Peradilan Agama, Jakarta: PT. Kencana, 2005, p. 175.

20 Simorangkir and Et.al, Kamus Hukum Jakarta: Sinar Grafika, 2004, p. 33.

21 Undang-undang Nomor 30 Tahun 1999 tentang Arbitrase dan Alternatif Penyelesaian Sengketa.

22 PERMA No. 1 Tahun 2016 tantang Prosedur Mediasi di Pengadilan. 
consultation; (3) The mediator is responsible for assisting the disputing parties to find a solution; (4) The mediator does not have the authority to make decisions during the consultation; (5) The purpose of mediation is to reach or produce an agreement accepted by the disputing parties in order to end the dispute.

As a mediator who is required to put forward compromise negotiations, he should have special skills. The specific skills referto: (1) Knowing how to listen to the disputing parties; (2) Having the skills to ask questions in dispute; (3) Having the skills to make decisions in resolving disputes which results will benefit the parties to the dispute (win-win solution); (4) Having equal negotiation skills; (5) Helping the parties to find their own solutions to the matters in dispute. ${ }^{23}$

The rules governing mediation are in PERMA No. 1 of 2016, which regulates the procedure for mediation, which includes general provisions, guidelines for mediation in court, mediators, pre-mediation stages, stages of the mediation process, voluntary reconciliation, separation of mediation from litigation, out of court peace, and closing provisions.

Basically, mediation in the Religious Courts is not different from the Courts in general, yet in special religious courts to mediate disputes that occur among Muslims, especially mediation in marriage cases, which is one of the jurisdictions of the Religious Courts.

Given the preamble to the Supreme Court Regulation No. 2 of 2003 revoked with PERMA No. 1 of 2008 concerning Mediation Procedures in Courts and finally PERMA No. 1 of 2016, emphasized that the integration of mediation into the court proceedings, can be an effective instrument in overcoming the possibility of case accumulation in the Court. The embryo of the birth of PERMARI Number 2 of 2003 was revoked with PERMA No. 1 of 2008 due to the number of cases in the Supreme Court, which prompted the Chief Justice of the Supreme Court at that time (Bagir Manan) to establish mediation as a way to reduce cases in the Judiciary, in particular at the Supreme Court. ${ }^{24}$

The persistence of the Supreme Court in integrating mediation institutions into court proceedings is intended as an effective instrument to overcome the problem of case buildup in court including divorce cases in PA as well as strengthening and maximizing the function of non-judicial institutions in dispute resolution in addition to judicial processes that are judicial in nature (adjudicative). ${ }^{25}$

23 Harijah Damis, Hakim Mediasi Versi Sema Nomor 1 Tahun 2002 Tentang Pemberdayaan Pengadilan Tingkat Pertama Menerapkan Lembaga Damai, Dalam Mimbar Hukum 63, Maret-April 2004.

24 Liliek Kamilah, Mediasi Sebagai Salah Satu Bentuk Penyelesaian Sengketa di Pengadilan Agama, Perspektif, Vol 15, No. 1 2010, hlm.50-63.

25 Triana Sofiani, Efektifitas Mediasi Perkara Perceraian Pasca PERMA Nomor 1 Tahun 2008 di Pengadilan Agama, Jurnal Penelitian, Vol.7, No. 22012. 
The background of the mediation application in dispute resolution according to Hasnawaty Abdullah in his writing entitled "The Application of Mediation in Judicial Practice", are: (1) The need for flexible and responsive dispute resolution procedures for the disputing parties; (2) Fostering community involvement in dispute resolution; (3) Expanding access to achieve or bring about justice so that every dispute that has its own characteristics is sometimes not in accordance with the form of settlement with one form of settlement, for this reason the parties can choose the best dispute resolution mechanism in accordance with the situation or the disputes being disputed. ${ }^{26}$

Basically, every civil dispute filed in the Religious Court, including the matter of resistance (verzet) on verdet decisions and the resistance of the parties (verdet party) and third parties (derden verzet) against the implementation of decisions that have the force of law, must first be resolved through mediation. However, based on Article 4 paragraph (2) of PERMA Number 1 of 2016, there are several civil disputes that are exempted from settlement obligations through mediation as follows: (1) Disputes whose examination at the trial is determined within the time of settlement in the provisions of legislation (such as application for revocation arbitration verdict); (2) A dispute in which its examination is conducted in the absence of the plaintiff or defendant who has been duly summoned; (3) Retaliation (reconstruction) and the third party involvement in a matter (intervention); (4) Disputes concerning the prevention, rejection, annulment and confirmation of marriage; (5) Disputes filed with the Religious Court after seeking settlement outside the Court through Mediation with the assistance of a certified Mediator registered in the local Court but declared unsuccessful based on a statement signed by the Parties and the certified Mediator. ${ }^{27}$

The mediation procedure in the Religious Courts is not different from the mediation procedures in other courts, all referring to PERMA No. 1 of 2016, which is not much different from the provisions of PERMA No. 1 of 2008, so that the mediation procedure refers to PERMA No. 8 of 2008. The following are the Mediation Procedures at Manado Religious Court.

\section{The Mediation Procedures at Manado Religious Court}

It is recorded in the Information System for Case Tracing of Manado Religious Court since January 2 2018, there are 2,138 28 cases handled by Manado Religious Court, both cases of divorce pursue and divorce, can be seen in table 1. Agama.

${ }^{26}$ Kamilah, Mediasi Sebagai Salah Satu Bentuk Penyelesaian Sengketa Di Pengadilan

27 Ibid.

28 Data diperoleh pada tanggal 20 November 2020 dapat di akses pada: http://sipp.pa-manado.go.id 
Table 1. Marriage Disputes since 2018-2020

\begin{tabular}{llccc}
\hline \multirow{2}{*}{ No. } & \multirow{2}{*}{ Cases } & \multicolumn{3}{c}{ Year } \\
\cline { 3 - 5 } & & 2018 & 2019 & 2020 \\
\hline 1. & Divorce & 124 & 144 & 141 \\
2. & Divorce Claim & 310 & 357 & 339 \\
\hline & Total & 434 & 501 & 480 \\
\hline
\end{tabular}

Source: Data processed from the Manado Religious Court Case Tracking Information System.

Based on the research data listed in the appendix; the Mediation as a form of Marriage Dispute Resolution at the Manado Religious Court, where this research uses a questionnaire to find out how all judges, clerks, lawyers and litigants at Manado Religious Court responded to our questions.

Mediation at the Manado Religious Court is one of the most important stages. This can be proven by the majority of informants agreeing to this statement, also proven by the existence of PERMA Number 1 of 2016 in article 4 paragraph (1) "All civil disputes filed to court including cases of resistance (verzet) over the verdict of verstek and resistance of litigants (partij verzet) and third parties (derden verzet) against the implementation of decisions that have permanent legal force, must first seek resolution through Mediation, unless otherwise stipulated by this Supreme Court Regulation".

Regarding the determination of the Mediator at Manado Religious Court, some informants agreed that the Mediator was determined by the Panel of Judges in a case while some of the informants were disagree. However, PERMA Number 1 of 2016 in article 3 paragraph (5) clearly regulates that the appointment of a Mediator is the authority of the Chair of the Court, and the Mediator referred to is the Mediator of Judges who is not Case Examining Judges. The obligation to follow PERMA No. 1 of 2016 is also explained in article 2, "Provisions regarding Mediation Procedures in this Supreme Court Regulation apply in court proceedings both in General Courts and Religious Courts." However, on the other hand, the parties who are involved are also given the opportunity to elect a Mediator as described in article 20 paragraph (1) to paragraph (3) then the Mediator will be immediately appointed by the chairman of the panel of Case Examining Judges as regulated in article 20 paragraph (4) up to paragraph (6).

The foregoing strengthens the statement that the Mediator at Manado Religious Court was well received by the parties in a case, whether the Mediator agreed by the parties or not, because the Mediator was appointed directly by the Chairman of the Court. Most informants also agreed to this.

Most informants agree that before the Mediator who handles a case starts mediation, he first must explain matters related to mediation. This is in line with the rules in PERMA Number 1 of 2016 in article 14 concerning the Stages of the Medator's Duties: (1) introduce themselves and giving opportunities to the Parties to introduce themselves to each other; (2) 
explain the purpose, purpose and nature of the Mediation to the Parties; (3) explain the position and role of the Mediator who is neutral and is not a decision maker; (4) make rules for the implementation of Mediation with the Parties; (5) explain that the Mediator can hold a meeting with one party without the presence of the other parties (caucus); (6) compile a schedule for Mediation with the Parties; (7) fill out the mediation schedule form; (8) provide an opportunity for the Parties to raise issues and proposals for peace; (9) to make an inventory of the problems and schedule discussions based on priority scale; (10) facilitate and encourage the Parties to explore and explore the interests of the Parties, seek various resolution options that are best for the Parties and work together to reach an agreement; (11) assist the Parties in drafting and formulating a Peace Agreement; (12) submits a report on the success, failure and / or inability of the Mediation to be carried out to the Case Examining Judge; (13) declare that one or the Parties are not in good faith and convey it to the Case Examining Judge; (14) other duties in carrying out their functions.

With PERMA Number 1 of 2016 in article 14 regarding the Medator's Stages of Duty above, the Mediator is obliged to provide advice and advice to the parties in a case. Furthermore, mediation is carried out in several stages which are detailed in PERMA Number 1 of 2016 in CHAPTER V concerning the Stages of the Mediation Process, articles 24 to article 32, and most informants stated that mediation in marriage cases was carried out more than once. The agreement in mediation is fully submitted to the parties without any intervention from the mediator as described in article 27 to article 31 PERMA Number 1 of 2016.

The Mediators in the Manado Religious Court while dealing with mediation matters, the parties to the case are not always present by their legal authorities. Most are attended by the parties to the case directly without being accompanied by legal authority or the party cannot attend the mediation process without being represented by legal authority. If the mediation process is attended by the legal authority then the legal authority must fulfill its obligations as regulated by Article 18 PERMA Number 1 of 2016.

Mediation is done after the parties have been legally and properly called. The call, must be fulfilled by the parties concerned so that the parties can fulfill the provisions of good faith in mediation as described in article 7 PERMA Number 1 of 2016 regarding the Obligation to Attend Mediation.

Most informants stated that the resolution of marital disputes through mediation can minimize the divorce rate at the Manado Religious Court. This can be proven by the presence of a mediator who seeks a peace agreement as stipulated in article 14 PERMA No.1 of 2016.

In line with the mentioned statement, the purpose of mediation is to produce an agreement between the parties in terms of resolving marital disputes, in order to avoid the risk of divorce. 
Thus, there needs to be a process of socialization to the community by the mediator regarding the mediation process. As well as the mediation procedures established by the Supreme Court.

Table. 2 The Cases of Marriage Dispute Resolution Through Mediation

\begin{tabular}{lllll}
\hline & Disputes & $\mathbf{2 0 1 5}$ & $\mathbf{2 0 1 6}$ & $\mathbf{2 0 1 7}$ \\
\hline $\mathbf{1}$ & Accepted & 347 disputes & 510 disputes & 359 disputes \\
$\mathbf{2}$ & Mediated & 106 disputes & 94 disputes & 76 disputes \\
$\mathbf{3}$ & Succesful mediation & 6 disputes & 3 disputes & 1 dispute \\
$\mathbf{4}$ & Failed mediation & 100 disputes & 91 disputes & 75 disputes \\
$\mathbf{5}$ & Unacceptable mediation & 241 disputes & 416 disputes & 1 dispute \\
\hline
\end{tabular}

Source: Data from the Manado Religious Court, 2015-2017

Mediation procedures and stages on marriage matters in Manado Religious Court need to be maximized to be further effective. It is evident from the data of the last 3 years that successful mediation is much less than failed mediation. In 2015, the mediation received was 347 cases, the mediation was 106 disputes, the successful mediation was only 6 cases while the failed ones were 100 cases and the other 241 cases were not eligible for mediation. In 2016, the mediation received was 510 cases, those mediated were 94, the successful mediation was only 3 cases while the failure was 91 cases and 416 other cases were not eligible for mediation. In 2017, the mediation received was 359 cases, the mediation was 76 cases, the successful mediation was only 1 case while the failure was 75 cases and 283 other cases were not eligible for mediation.

It is true that the process of resolving marital disputes through mediation is based on the principle of negotiation in accordance with the mandate of PERMA No.1 of 2016. Even the mediation procedure is in accordance with the rules, but the data above explicitly explain that each year there are fewer successful mediations. This indicates that mediation PA in Manado has not been as effective as expected.

According to Soekanto, there are four indicators to measure the effectiveness of a regulation: first, it is returned to the law itself; second, the officers who enforce it; third, facilities that support law enforcement; and fourth, the members of the community who are subject to regulation. ${ }^{29}$

The first factor, is returned to the law or regulation itself. According to Fuller, every regulation (statute, government regulation, etc.) must comply with the eight principles of legality; ${ }^{30}(1)$ There must be norms and rules which are first adopted in society; (2) Regulations made must be properly socialized, not only in legal fiction, that everyone is deemed to know the law immediately after it is promulgated; (3) The formulation of rules is made

\footnotetext{
${ }^{29}$ Sofiani, Efektifitas Mediasi Perkara Perceraian Pasca PERMA Nomor 1 Tahun 2008 di Pengadilan Agama.

30 bid.
} 
clearly to avoid legal interpretation; (4) Regulations may not apply retroactively, in accordance with the universally applicable legality principle; (5) The law regulates concrete and realistic matters, so that they are easy to implement; (6) Laws should not conflict with one another; (7) The law must be consistent, change infrequently or be adhoc; (8) There is compatibility between regulations and daily implementation.

In the description of the research results, some informants stated that the procedures and steps for mediation in marriage cases at the Manado Religious Court need to be maximized and to be more effective. However, some did not agree with this because they thought that the mediation steps at Manado Religious Court were in accordance with existing regulations and had been maximally and effectively implemented.

However, it is clear from the data of the last 3 years that successful mediation is much less than failed mediation. That is, in 2015 , the mediation received was 347 cases, the mediation was 106 cases, the successful mediation was only 6 cases, while the failed ones were 100 cases and the other 241 cases were not eligible for mediation. In 2016, the mediation received was 510 cases, the mediation was 94 cases, the successful mediation was only 3 cases while the failure was 91 cases and 416 other cases were not eligible for mediation. In 2017, the mediation received was 359 cases, the mediation was 76 cases, the successful mediation was only 1 case while the failure was 75 cases and 283 other cases were not eligible for mediation.

Seeing that the consideration of the issuance of PERMA Number 1 of 2016 concerning Mediation Procedures in Courts, mediation in general and religious courts is expected to have an impact on the bureaucratic reform of the Supreme Court of the Republic of Indonesia which is oriented towards the vision of realizing a great Indonesian judicial. One of the supporting elements is Mediation as an instrument to increase public access to justice as well as the implementation of the principles of simple, fast, and low cost judicial administration.

However, in reality there have been very few cases which were successfully mediated. Although informants stated that the settlement of marriages through mediation can minimize the divorce rate at Manado Religious Court. However, it cannot be denied that the Mediators at Manado Religious Court are really trying to reconcile the parties in litigation.

This was indicated by the majority of informants stating that the mediation of marital cases did not result in an agreement between the parties, so that the mediation was considered a failure.

\section{Closing}

There are several ways of resolving disputes in court, they are Negotiation, Mediation, Conciliation, Litigation / Court, and Arbitration. The method of dispute resolution through mediation is regulated in PERMA No. 1 of 2016 on Mediation Procedures in Courts. The settlement of marital disputes through 
mediation in the religious court system is not different from courts in general because it refers to PERMA No. 1 of 2016.

Some important elements in mediation include the following: (1) Mediation is the process of dispute resolution based on negotiation; (2) The mediator is involved and accepted by the disputing parties in the consultation; (3) The mediator is responsible for assisting the disputing parties to find a solution; (4) The mediator does not have the authority to make decisions during the consultation; (5) The purpose of mediation is to reach or produce an agreement accepted by the disputing parties in order to end the dispute.

As a mediator who is required to prioritize compromised negotiations, he should have special skills. The specific skills referred to are: (1) Knowing how to listen to the disputing parties; (2) Having the skills to ask questions in dispute; (3) Having the skills to make choices in resolving disputes which results in benefit the parties to the dispute (win-win solution); (4) Having equal negotiation skills; (5) Helping the parties to find their own solutions to the matters being disputed.

\section{Bibliography}

Abbas, Syahrisal, Mediasi Dalam Hukum Syariah, Hukum Adat. \& Hukum Nasional, Jakarta: Kencana, 2011.

Adiyono, Mediasi Sebagai Upaya Hakim Menekan Perceraian di Pengadilan Agama, Al- Ihkam, No. 8, 2013.

Ali, Atabik, and Ahmad Zuhdi Muhdlor, Kamus Kontemporer (Arab-Indonesia). Yogyakarta: Multi Karya Grafika, 1999.

Amriani, Nurnaningsih, Mediasi Alternatif Penyelesaian Sengketa Perdata di Pengadilan, Jakarta: Rajawali Press, 2012.

Aprilda, Pengaruh Kompetensi Terhadap Prestasi Kerja Pegawai (Studi Pada Bagian Pengelolaan Keuangan Balai Pengembangan Pendidikan Nonformal dan Informal Regional I Medan) Pemerintah Provinsi Sumatera Utara Pengetahuan, Keahlian dan Sikap Prilaku Tugasnya, Jurnal Administrasi Publik, no. 2, 2012.

Besse, Noval, Praktik Mediasi Pada Badan Penasehatan Pembinaan dan Pelestarian Perkawinan di Kabupaten Minahasa Utara, Aqlam: Journal of Islam and Plurality, Vol. 3, No. 2. 2018.

Damis, Harijah, Hakim Mediasi Versi Sema Nomor 1 Tahun 2002 Tentang Pemberdayaan Pengadilan Tingkat Pertama Menerapkan Lembaga Damai, Dalam Mimbar Hukum 63, Maret-April 2004.

Gunawan, Edi, and Faradila Hasan, Divorce Lawsuit Due to Polygamy in the Manado Religious Court, Al-Mizan, Vol.13, No. 2 December, 2017.

Hamidah, Zahrotul, Peran Badan Penasihat, Pembinaan dan Pelestarian Perkawinan (BP4) dalam Mencegah Perceraian (Studi Kasus di KUA Kecamatan Klojen Kota Malang, HIKMATINA: Jurnal Ilmiah Hukum, No. 1, 2019. 
Jamal, Ridwan, Resolusi Konflik Perkawinan Melalui Mediasi dalam Perkara Perceraian di Pengadilan Agama Manado, Jurnal Ilmiah Al-Syir'ah, Vol. 15, No. 2, 2017.

Kamilah, Liliek, Mediasi Sebagai Salah Satu Bentuk Penyelesaian Sengketa di Pengadilan Agama, Perspektif, Vol. 15, No. 1, 2010.

Manan, Abdul, Penerapan Hukum Acara Perdata di Lingkungan Peradilan Agama, Jakarta: PT. Kencana, 2005.

Mashuri, Mediasi Di Pengadilan Agama Berdasarkan Peraturan Mahkamah Agung Nomor 1 Tahun 2016, Accessed November 22, 2020, http://www.arsip.pa-manna.go.id/wpcontent/uploads/2015/03/DISKUSI-HUKUM-MEDIASI.pdf.

Mustakid, Dodo, Proses Mediasi Perkara Perceraian di Peradilan Agama, Jurnal Edu Law : Jurnal Of Islamic Law and Yurisprudance Proses, Vol. 1, No. 1, 2020.

Pengadilan Agama Manado, Sistem Informasi Penelusuran Perkara, Pengadilan Agama Manado. Accessed November 22, 2020, http://sipp.pa-manado.go.id/list_perkara.

PERMA RI No. 2 Tahun 2003 tantang Prosedur Mediasi di Pengadilan.

PERMA No. 1 Tahun 2008 tantang Prosedur Mediasi di Pengadilan.

PERMA No. 1 Tahun 2016 tantang Prosedur Mediasi di Pengadilan.

Putri, Febry Andika, Indra Perdana, and Emiel Salim Siregar, Peranan Hakim Sebagai Mediator dalam Proses Mediasi untuk Menangani Perkara Perceraian (Studi di Pengadilan Agama Kisaran Nomor : 1414/Pdt.G/2019/PA.Kis.), Vol. 1, No. 2, 2020; Rahmawati, Erik Sabti, Implikasi Mediasi Bagi Para Pihak yang Berperkara di Pengadilan Agama Malang, De Jure: Jurnal Hukum dan Syar'iah, Vol. 8, No. 1. 2016; Samsukadi, Mochamad, and Ahmad Abdu, Efektifitas Mediasi dalam Menyelasaikan Konflik Pernikahan di Pengadilan Agama Jombang Tahun 2013-2014, Jurnal Hukum Keluarga Islam, Vol.1, No. 1, 2016.

Sembiring, Jimmy Joses, Cara Menyelesaikan Sengketa di Luar Pengadilan Negosiasi, Mediasi, Konsiliasi \& Arbitrase, Jakarta: Visimedia, 2011.

Simorangkir, and Et.al, Kamus Hukum, Jakarta: Sinar Grafika, 2004.

Soemartono, Gatot P, Arbitrasedan Mediasi di Indonesia, Jakarta: PT. Gramedia Pustaka Utama, 2006.

Sofiani, Triana, Efektifitas Mediasi Perkara Perceraian Pasca PERMA Nomor 1 Tahun 2008 di Pengadilan Agama, Jurnal Penelitian, Vol.7, No. 2, 2012.

Undang-undang Nomor 30 Tahun 1999 tentang Arbitrase dan Alternatif Penyelesaian Sengketa.

Wirhanuddin, Deskripsi Tentang Mediasi di Pengadilan Tinggi Agama Makassar: Perspektif Hukum Islam, $A L-F I K R$, Vol. 20, No. 2, 2016. 